Article

\title{
Effects of White Lupin and Groundnut on Fractionated Rhizosphere Soil P of Different P-Limited Soil Types in Japan
}

\author{
Kaoru Imai ${ }^{1}$, Soh Sugihara ${ }^{1, *(1)}$, Jun Wasaki ${ }^{2}$ and Haruo Tanaka ${ }^{1}$ \\ 1 Graduate School of Agriculture, Tokyo University of Agriculture and Technology, 3-5-8 Saiwai-cho, \\ Fuchu-shi, Tokyo 183-8509, Japan; s170501u@st.go.tuat.ac.jp (K.I.); haruo@cc.tuat.ac.jp (H.T.) \\ 2 Graduate School of Biosphere Science, Hiroshima University, Kagamiyama 1-7-1, Higashi-Hiroshima-shi, \\ Hiroshima 739-8521, Japan; junw@hiroshima-u.ac.jp \\ * Correspondence: sohs@cc.tuat.ac.jp; Tel.: +81-42-367-5676
}

Received: 25 December 2018; Accepted: 30 January 2019; Published: 2 February 2019

check for updates

\begin{abstract}
Phosphorus $(\mathrm{P})$ is an essential nutrient for crop production, while most soil $\mathrm{P}$ is the less labile $\mathrm{P}$ associated with Aluminum (Al) and Iron (Fe) in acidic soils of Japan. The objectives of this study were to evaluate the effects of two contrasting P-efficient legumes (white lupin, WL (Lupinus albus L.); and groundnut, GN (Arachis hypogaea L.)) on rhizosphere soil P dynamics in different soil types of Japan, such as Al-rich volcanic-soil, Fe-rich red-yellow-soil, and sandy-soil, with or without historical fertilization managements ( 3 soil types $\times 2$ managements $=6$ soil samples). We conducted a 56-day pot experiment, and analyzed the plant $\mathrm{P}$ uptake and fractionated $\mathrm{P}$ of rhizosphere and bulk soils, based on the Hedley-fractionation method. We observed that GN P uptake was generally larger than that in WL in most soil types and managements. WL significantly decreased the labile $\mathrm{P}$ in most soils and also decreased the less labile inorganic $\mathrm{P}\left(\mathrm{P}_{\mathrm{i}}\right)$ and organic $\mathrm{P}\left(\mathrm{P}_{\mathrm{o}}\right)$ in fertilized Red-yellow-soil, which has much crystalline Fe, though GN did not. In contrast, both WL and GN significantly decreased the less labile $P_{i}$ in fertilized volcanic-soil, which has much non-crystalline Al. These results indicate that (1) characteristics of less labile P uptake by P efficient legumes were different between the soil types and managements, and (2) WL efficiently solubilized the less labile P than GN in fertilized red-yellow soil, while GN efficiently absorbed the larger amount of $\mathrm{P}$ than $\mathrm{WL}$, especially in volcanic- and sandy-soil.
\end{abstract}

Keywords: P fractionation; white lupin; groundnut; rhizosphere; soil properties

\section{Introduction}

Phosphorus $(\mathrm{P})$ is an essential element of plant metabolism (for example, it is a constituent of nucleic acids and membranes), and chemical or organic $P$ fertilization is usually necessary to increase crop productivity. However, most applied $\mathrm{P}$ fertilizer is easily converted to a less labile $\mathrm{P}$ form in the soil, due to the association with the surface area of various clay minerals and iron ( $\mathrm{Fe}) /$ aluminum (Al) oxides; for example, $\mathrm{Fe} / \mathrm{Al}$ oxides in acidic soils, calcium (Ca) and magnesium (Mg) minerals in neutral to alkaline soils [1], and the Al-humus complexes in volcanic soil [2]. These associated P in soil cannot be utilized by most crop species, and therefore, the P use efficiency of $\mathrm{P}$ fertilizer is generally low [3], and P deficiency is one of the major limitations for crop growth and productivity [4]. Furthermore, phosphate rock, which is the source of manufactured P fertilizer, is a finite resource $[5,6]$, and the warning has been expressed that current mining rates would lead to a rapid depletion of $P$ resources in the near future [7]. Thus, it is necessary to improve the soil-crop P dynamics by using less labile $\mathrm{P}$ to achieve the sustainable agriculture for the coming decades and centuries [8]. 
Many studies have focused on several legume species (i.e., P-efficient legume), which can effectively mobilize and utilize the less labile $\mathrm{P}$ associated with $\mathrm{Al}, \mathrm{Fe}$, and $\mathrm{Ca}$, compared with cereal plants [9-12]. In general, P-efficient legumes secrete large quantities of organic acids such as malate, citrate, and oxalate for utilizing inorganic $\mathrm{P}$ and/or acid phosphatases from their roots for hydrolyzing organic $\mathrm{P}[4,13,14]$. These P-efficient legume species include white lupin (Lupinus albus L.; [15,16], groundnut (Arachis hypogaea L.; [17,18], pigeon pea (Cajanus cajan L.; [19], and chickpea (Cicer arietinum L.; [20]. The accumulated P forms and its availability in soil are generally controlled by soil physico-chemical properties such as $\mathrm{pH}$, soil texture, and the amounts and forms of $\mathrm{Al}, \mathrm{Fe}$, and $\mathrm{Ca}[1,21]$. Sugihara et al. [22] observed that the rhizosphere soil $\mathrm{P}$ dynamics of various P efficient legumes (white lupin, cowpea (Vignaungui culata L.), and pigeon pea) were significantly different for different soil physico-chemical properties, such as the amount of crystalline Fe or clay content, in Tanzania. Dissanayaka et al. [23] also found that effect of intercropped white lupin on maize P uptake is dependent on soil type, for example, white lupin had a high ability to improve the maize P uptake in Regosol, but not in Andisol. Rose et al. [8] also found that some crops (wheat, faba bean, canola, and chickpea) can decrease the less labile $\mathrm{P}$, i.e., $\mathrm{NaOH}$ extractable $\mathrm{P}_{\mathrm{i}}$, only in alkaline soil, but not in acidic soil. These studies indicate that each P-efficient legume may have the specific soil condition, to utilize the less labile P [19]. Therefore, it is necessary to consider and evaluate the effect of soil physico-chemical properties on soil-legumes P dynamics, especially for less labile P dynamics, to achieve the better $\mathrm{P}$ use efficiency by utilizing the suitable P-efficient legume for each soil type.

In Japan, various soil types are distributed as croplands, and certain soil types are well known for their high P fixation capacity or inherently low soil P [24,25]; the following three soil types should be the important cropland soil to improve the P-use efficiency in Japan: (1) Volcanic soils (classified as Andisols), which have critically high $P$ fixation capacity of soils, caused by their much non-crystalline $\mathrm{Al}$ oxides, i.e. allofhane and imogolite [26,27], and cover ca. 50\% of upland areas in Japan; (2) strongly weathered red-yellow soils (classified as Inceptisols or Ultisols), which have a strong P fixation capacity, caused by much crystalline Fe oxide and large amounts of clay contents [28], and distributed mainly in southern Japan, Okinawa prefecture [29]; and (3) sandy soils (classified as Entisols), which are coarse textured (i.e., sandy) soils and have an inherently low total soil P and low P fixation capacity, due to small amounts of $\mathrm{Al}$ and $\mathrm{Fe}$ oxides [23,30], distributed mainly in the mountains or coastal region of western Japan. These three soil types have similar P-deficient problems for crop production, though are likely to have different mechanisms causing their low P-use efficiency as a result of their different $\mathrm{P}$ absorbed capacities and accumulated $\mathrm{P}$ forms. For example, in volcanic soil, most of less labile $\mathrm{P}$ should be associated with non-crystalline $\mathrm{Al}$ and $\mathrm{Al}$-humus complexes, while it should be associated with crystalline Fe in red-yellow soils, and in sandy soils, less labile P should be a few contents caused by a low amount of $\mathrm{Al}$ and $\mathrm{Fe}$. At present, there are many studies about the effect of soil characteristics on fractionated rhizosphere soil P of P efficient legumes but most of these studies were conducted in neutral or alkaline soil $[8,12,31]$. Thus, there is little qualitative information about the effect of soil physico-chemical properties (e.g., the quantities and type of $\mathrm{Al}$ and $\mathrm{Fe}$, or low soil $\mathrm{pH}$ ) on less labile $\mathrm{P}$ uptake and utilize capability of P-efficient legume rhizosphere in acidic cropland soils of Japan [23], even though such information would be useful to improve soil-crop P dynamics using P-efficient legumes in the future.

Therefore, the objectives of this study were (1) to investigate the effects of two different legumes (white lupin and groundnut) on rhizosphere soil $\mathrm{P}$ dynamics in different $\mathrm{P}$-limited soil types with the Hedley fractionation method [32], and (2) to compare the effects of soil physico-chemical properties on legume P uptake and soil P dynamics, based on volcanic soils, red-yellow soils, and sandy soils of Japan. To evaluate the effect of land management (esp. for P condition) on rhizosphere P dynamics of each soil [33], we used two different land management soils from each soil type, i.e., P-poor soil (no-cultivation and/or no-fertilization) and P-rich soil with historical fertilization. Our study fundamentally examined the early stage growth of the two legumes, i.e., white lupin and groundnut, and conducted a pot experiment in a temperature-controlled glasshouse. 


\section{Materials and Methods}

\subsection{Soils}

We used three different soil types and two different land management soils of Japan ( 3 soil types $\times 2$ managements $=6$ soil samples) with different physico-chemical properties, in order to compare the soil-plant $P$ dynamics between the various soil types and land management: A volcanic soil (Andisols) with and without cultivation and fertilizer, a red-yellow soil (Inceptisols), with and without cultivation and fertilizer, a sandy soil (Entisols) with and without fertilizer [34]. Volcanic soil samples were collected from the experimental field of Tokyo University of Agriculture and Technology at Fuchu, Japan; one is named "Andisols" ( $35^{\circ} 41^{\prime} \mathrm{N}$ and $\left.139^{\circ} 29^{\prime} \mathrm{E}\right)$, where the field had never been cropped or fertilized for $>100$ years (conservation area), and the vegetation is a deciduous broadleaf forest, and the other is named "Andi-Fer"(ca. $700 \mathrm{~m}$ from Andisols site), where compost and chemical fertilizer had been applied for $>25$ years as long-term experimental cropland field (maize, soybean, and so on). Red-yellow soil samples were collected from the Okinawa prefecture of Japan; one is named "Inceptisols" ( $26^{\circ} 41^{\prime} \mathrm{N}$ and $\left.128^{\circ} 06^{\prime} \mathrm{E}\right)$, where it had never been cropped and fertilized before, and the vegetation is a young tropical forest, and the other is named "Incepti-Fer" $\left(25^{\circ} 57^{\prime} \mathrm{N}\right.$ and $\left.131^{\circ} 19^{\prime} \mathrm{E}\right)$, where chemical fertilizer was generally applied for $>30$ years, according to the recommendation of Okinawa prefecture. Sandy soil samples were collected from a long-term experimental cropland field of Hiroshima University at Higashi Hiroshima, Japan; one is named "Entisols" $\left(34^{\circ} 23^{\prime} \mathrm{N}\right.$ and $132^{\circ} 43^{\prime} \mathrm{E}$ ), where it had never been fertilized for 28 years and conducted the cultivation, and the other is named "Enti-Fer" $\left(34^{\circ} 23^{\prime} \mathrm{N}\right.$ and $\left.132^{\circ} 43^{\prime} \mathrm{E}\right)$, where it had been fertilized (with nitrogen, phosphorus and potassium) for 28 years and conducted the cultivation. Soil physico-chemical properties are shown in Table 1. Andisols and Andi-Fer soils have much non-crystalline Al oxides (oxalate-extractable $\mathrm{Al} ; \mathrm{Al}_{\mathrm{o}}$ ), due to the volcanic materials, while Inceptisols and Incepti-Fer have much crystalline $\mathrm{Fe}$ oxides (dithionite-citrate- bicarbonate extractable $\mathrm{Fe} ; \mathrm{Fe}_{\mathrm{d}}$ ). In contrast, Entisols and Enti-Fer has little $\mathrm{Al}$ and $\mathrm{Fe}$ oxides due to little clay content. Soil $\mathrm{pH}$ was relatively low (5.1-5.5), except for Andi-Fer (6.7), as a result of the neutralization management only at this site. Available P, such as Bray2-P was significantly larger in fertilized soils, due to the fertilization management. The $\mathrm{P}$ absorption capacity [35] is significantly higher in volcanic soils than Red-yellow soils and HS. In this study, we compared with the soil types for Andisols, Inceptisols, and Entisols, while we also compared the effect of land management including fertilization and / or neutralization management for each soil type (e.g., Andisols vs Andi-Fer). All soils were collected from the surface soil layer $(0-15 \mathrm{~cm})$. The soils were air-dried and passed through a $4 \mathrm{~mm}$ sieve, and whole visible plant residues were removed before the experiment. 
Table 1. Soil physico-chemical properties.

\begin{tabular}{|c|c|c|c|c|c|c|c|c|c|c|c|}
\hline & \multicolumn{2}{|c|}{ Soil pH } & TC & TN & \multirow{2}{*}{ Clay (\%) } & $\mathrm{Al}_{\mathrm{o}}$ & $\mathrm{Fe}_{\mathrm{o}}$ & $A 1_{d}$ & $\mathrm{Fe}_{\mathrm{d}}$ & \multirow{2}{*}{ Bray-P (mg P kg-1) } & \multirow{2}{*}{$\begin{array}{c}\text { P Ads. Cap. } \\
\left(\mathrm{mg} \mathrm{P}_{2} \mathrm{O}_{5} 100 \mathrm{~g}^{-1}\right.\end{array}$} \\
\hline & $\left(\mathrm{H}_{2} \mathrm{O}\right)$ & (KCl) & \multicolumn{2}{|c|}{$\left(\mathrm{g} \mathrm{kg}^{-1}\right)$} & & \multicolumn{4}{|c|}{$\left(\mathrm{g} \mathrm{kg}^{-1}\right)$} & & \\
\hline Andisols & 5.3 & 4.6 & 94.3 & 6.5 & 27.9 & 63.8 & 29.6 & 21.5 & 55.5 & 11.7 & 2237.2 \\
\hline Andi-Fer & 6.7 & 5.6 & 90.7 & 7.1 & 36.6 & 65.9 & 28.3 & 19.1 & 59.6 & 112.9 & 2072.3 \\
\hline Inceptisosl & 5.1 & 3.2 & 18.4 & 1.9 & 30.7 & 2.9 & 1.6 & 5.4 & 35.3 & 9.4 & 686.5 \\
\hline Incepti-Fer & 5.1 & 4.3 & 19.8 & 2.1 & 88.7 & 2.2 & 1.9 & 10.1 & 61.0 & 373.0 & 816.2 \\
\hline Entisols & 5.5 & 4.1 & 2.4 & 0.2 & 4.4 & 0.5 & 0.4 & 0.1 & 4.4 & 6.5 & 130.6 \\
\hline Enti-Fer & 5.5 & 3.4 & 2.6 & 0.3 & 6.0 & 1.5 & 0.6 & 1.1 & 4.8 & 119.2 & 130.2 \\
\hline
\end{tabular}
of soil. 


\subsection{Plant Growth Conditions}

The experiment was conducted in a phytotron, i.e., outside an enclosed glasshouse, which can control the temperature $\left(28.0-18.0^{\circ} \mathrm{C}\right.$, day-night regime) and humidity under natural sunlight. Wagner pots $(1 / 5000$ a) were used for the pot experiment. Based on the preliminary measured bulk density for all soils, the amount of soil to be placed in each pot was calculated to simulate the field conditions (2.0 kg pot ${ }^{-1}$ in Andisols and Andi-Fer, $2.5 \mathrm{~kg} \mathrm{pot}^{-1}$ in Inceptisols and Incepti-Fer, and $4.0 \mathrm{~kg} \mathrm{pot}^{-1}$ in Entisols and Enti-Fer). For Inceptisols and Incepti-Fer soils, we used the relatively light bulk density which was measured immediately after the machinery cultivation $\left(0.79 \mathrm{Mg} \mathrm{m}^{-3}\right)$, because the normal bulk density (ca. $1.05 \sim 1.15 \mathrm{Mg} \mathrm{m}^{-3}$ ) prevent the plant growth and root penetration, due to the hard compactness, based on our pre-experiments. Soil moisture conditions were maintained at $60 \%$ of field capacity (except for Entisols and Enti-Fer, which were maintained at $30 \%$ of field capacity, because high moisture contents in sandy soils had caused moisture damage to plants in our pre-experiments) during the experiment by daily weight and watering.

We used two plant species, i.e., white lupin (Lupinus albus L. cv. Luxor; WL) and groundnut (Arachis hypogaea L. cv. Chibahandachi; GN). WL has a strong potential to improve the soil P dynamics even in the volcanic soil [23] and GN also has the strong potential to utilize the less labile inorganic P [17]. The WL and GN seeds were surface-sterilized using 1\% sodium hypochlorite and $70 \%$ ethanol, and were soaked in tap water over 3 days for germination. After radicle emergence, four evenly sized seeds per pot were planted. Two weeks after planting, the plants were thinned to two plants per pot. Five replications were prepared for each soil type ( 2 legumes $\times 6$ soil types $\times 5$ replication $=60$ pots). Unplanted pots, serving as controls and representing the bulk soil (Ctrl), were also prepared and the moisture content of bulk soil was similarly maintained at 60\% (30\% for Entisols and Enti-Fer) of field capacity (three replications). In this research, we did not apply $\mathrm{P}$ and $\mathrm{N}$ fertilization to all soils because $\mathrm{P}$ dynamics of soils are theoretically affected by $\mathrm{P}$ and $\mathrm{N}$ fertilization and we wanted to evaluate the original $\mathrm{P}$ dynamics of each soil. To minimize the limitation of nutrients other than $\mathrm{P}$ and $\mathrm{N}$, nutrients were supplied at the following rates: Macronutrients $\left(\mathrm{g} \mathrm{kg}^{-1}\right.$ soil): $\mathrm{K}_{2} \mathrm{SO}_{4} 0.17$ and $\mathrm{MgSO}_{4} \cdot 7 \mathrm{H}_{2} \mathrm{O} 0.39$; and micronutrients (mg kg ${ }^{-1}$ soil): FeNa-EDTA 0.4, $\mathrm{CuSO}_{4} \cdot 5 \mathrm{H}_{2} \mathrm{O} 2.0, \mathrm{MnSO}_{4} \cdot 5 \mathrm{H}_{2} \mathrm{O} 0.6, \mathrm{CoCl}_{2} \cdot 6 \mathrm{H}_{2} \mathrm{O}$ $0.4, \mathrm{H}_{3} \mathrm{BO}_{3} 0.5, \mathrm{Na}_{2} \mathrm{MoO}_{4} \cdot 2 \mathrm{H}_{2} \mathrm{O} 0.5$ and $\mathrm{ZnSO}_{4} \cdot 7 \mathrm{H}_{2} \mathrm{O} 2.2$ [12]. All pots were arranged in a complete randomized design in the glasshouse. Plants and soils were sampled 56 days after planting.

\subsection{Plant and Soil Analyses}

At sampling, the aboveground biomass (stem and leaves) were cut at the soil surface, rinsed in tap water and then oven-dried at $70{ }^{\circ} \mathrm{C}$ for more than 2 days. The dried plant samples were then weighed. The P content was determined calorimetrically with the molybdate-ascorbic acid procedure [36], following digestion with nitric and sulfuric acid. To correct the belowground biomass (roots) and rhizosphere soil, root systems were carefully removed from the pots and lifted. The root system was shaken gently to remove loosely adhering soil. The rhizosphere soils (i.e., strongly adhering soil and therefore were strongly affected by plant root) were collected by another careful shaking of the root system in a plastic bag and/or by carefully brushing the rhizosphere soil from the root surfaces. There was more than $20 \mathrm{~g}$ of rhizosphere soil per pot for each legume species and soil type. Unplanted pots were also prepared for each pot experiment, and were used to collect bulk soil $\left(C_{\text {trl }}\right)$, in order to reduce the number of soil analytical samples of bulk for labor saving. To verify the suitability of the $C_{\text {trl }}$ soil as the bulk soil sample, we also analyzed the bulk soil (not rhizosphere soil) of several planted pots and compared the fractionated soil $\mathrm{P}$ of bulk soil of planted pots with that of the $\mathrm{C}_{\mathrm{trl}}$ soil. These results confirmed that there were no clear differences between the bulk soil of planted pots and $C_{\text {trl }}$ soil, and therefore we could use the $C_{\text {trl }}$ soil as the control soil sample for all planted rhizosphere soils. The rhizosphere soil and $\mathrm{C}_{\text {trl }}$ soil were stored in the refrigerator at $4{ }^{\circ} \mathrm{C}$. After sampling, soil samples were passed through a $2 \mathrm{~mm}$ sieve, and visible plant residues and roots were carefully removed. Soils were then kept in a refrigerator at $4{ }^{\circ} \mathrm{C}$, for analysis of soil $\mathrm{pH}$, total $\mathrm{P}$, and fractionated $\mathrm{P}$ as described below. 
Phosphorus fractionation of soil was conducted using a modified Hedley fractionation [32]. In brief, $0.5 \mathrm{~g}$ of rhizosphere and $\mathrm{C}_{\mathrm{trl}}$ soil sample were placed in a $50 \mathrm{~mL}$ centrifuge tube and extracted sequentially with the solutions in the following order: (1) $30 \mathrm{~mL}$ distilled water with two resin strips (anion exchange resins in the bicarbonate form; Resin-P); (2) $30 \mathrm{~mL}$ of $0.5 \mathrm{M} \mathrm{NaHCO}_{3}$ adjusted to $\mathrm{pH} 8.5$ ( $\left.\mathrm{NaHCO}_{3}-\mathrm{P}\right)$; (3) $30 \mathrm{~mL}$ of $0.1 \mathrm{M} \mathrm{NaOH}(\mathrm{NaOH}-\mathrm{P})$; and (4) $20 \mathrm{~mL}$ of $1 \mathrm{M} \mathrm{HCl}(\mathrm{HCl}-\mathrm{P})$. Each extraction was performed for $16 \mathrm{~h}$ using a horizontal shaker followed by centrifugation at $2210 \mathrm{~g}$ for $20 \mathrm{~min}$ at room temperature. The inorganic $\mathrm{P}\left(\mathrm{P}_{\mathrm{i}}\right)$ concentration in all extracts was measured colorimetrically with the molybdate-ascorbic acid procedure [36] after $\mathrm{pH}$ adjustment to $7.08 \mathrm{using} p$-nitrophenol as an indicator of colorimetric titration. The absorbance was determined at $712 \mathrm{~nm}$. The total $\mathrm{P}\left(\mathrm{P}_{\mathrm{t}}\right)$ in each $\mathrm{NaHCO}_{3}$ and $\mathrm{NaOH}$ extract was measured after digestion in ammonium persulfate in an autoclave at $103.5 \mathrm{kPa}$ and $120^{\circ} \mathrm{C}\left(60 \mathrm{~min}\right.$ for the $\mathrm{NaHCO}_{3}$ extract and $90 \mathrm{~min}$ for the $\mathrm{NaOH}$ extract). The organic $\mathrm{P}(\mathrm{Po})$ was calculated as the difference between $\mathrm{Pt}$ and Pi. Pt of rhizosphere and bulk soil samples were determined using the vanadomolybdate yellow method [37] after wet digestion with nitric acid and perchloric acid. The total soil P measurement of Entisols was substantially small and thus we used the molybdate-ascorbic acid procedure for accuracy. Residual $\mathrm{P}$ was calculated as the difference between the total $\mathrm{P}$ and the sum of all organic and inorganic $\mathrm{P}$ fractions of extracts. The Resin $\mathrm{P}$ and $\mathrm{NaHCO}_{3}$-extractable $\mathrm{P}$ are labile $\mathrm{P}$ forms, whereas $\mathrm{NaOH}$-extractable $\mathrm{P}, \mathrm{HCl}-\mathrm{P}$ and Residual-P were classified as a less labile $\mathrm{P}$ form, which is not generally available to plants [38]. Soil $\mathrm{pH}$ (soil:water = 1:5, $w / w)$ was also measured for each soil sample.

\subsection{Data Analysis}

All statistical analyses were performed with SYSTAT 12.5 (SYSTAT Software, Richmond, CA, USA). All data are expressed on a dry weight basis. All variables were tested for normality of the distribution by a Shapiro-Wilk test, and transformed when necessary to minimize variation. One-way analysis of variance (ANOVA) was used to analyze the plant related values (biomass, $\mathrm{P}$ concentration and its uptake), each $\mathrm{P}$ fraction and soil $\mathrm{pH}$ between the $\mathrm{C}_{\mathrm{trl}}, \mathrm{WL}$, and $\mathrm{GN}$ rhizosphere soil for each soil type and management. When ANOVA indicated a significant difference, mean comparisons were carried out using post-hoc Tukey multiple comparison tests. In addition, to access the effect of soil types and land management on the plant P uptake of WL and GN, we conducted a 2-way ANOVA. In all cases, $p<0.05$ was considered significant.

\section{Results}

\subsection{Plant Growth and P Uptake}

The plant biomass, P concentration, and P uptake of WL and GN in all soils after the pot experiment are shown in Table 2. The aboveground biomass of WL was significantly higher in Andi-Fer and Incepti-Fer than in other soils, while the aboveground biomass of GN was significantly higher in Andi-Fer than in other soils. The belowground biomass of each plant also showed a similar trend as aboveground biomass. The cluster roots of WL were observed in every soil type, though the number or size of cluster roots were not clearly different for all soil types and managements. Generally, both aboveground and belowground biomass of GN were significantly larger than those of WL in whole soil types and managements, except for aboveground biomass in Incepti-Fer. The P concentration of WL was significantly higher in Incepti-Fer than in other soils. The P concentration of GN was higher in Enti-Fer (Above) and Incepti-Fer (Below). Total plant $P$ uptake of WL decreased in the following order: Incepti-Fer $\left(49.9 \mathrm{mg} \mathrm{P} \mathrm{pot}^{-1}\right)>$ Andi-Fer $\left(28.9 \mathrm{mg} \mathrm{P}\right.$ pot $\left.^{-1}\right)>\operatorname{Enti-Fer}\left(11.3 \mathrm{mg} \mathrm{P} \mathrm{pot}^{-1}\right)>\operatorname{Entisols}\left(3.5 \mathrm{mg} \mathrm{P} \mathrm{pot}^{-1}\right)$, Andisols (1.3 mg P pot ${ }^{-1}$ ) and Inceptisols $\left(0.8 \mathrm{mg} \mathrm{P}\right.$ pot $\left.^{-1}\right)$, while that of GN was as follows: Andi-Fer (55.4 $\left.\mathrm{mg} \mathrm{P} \mathrm{pot}^{-1}\right)>$ Enti-Fer $\left(46.0 \mathrm{mg} \mathrm{P} \mathrm{pot}^{-1}\right)$ and Incepti-Fer $\left(39.7 \mathrm{mg} \mathrm{P} \mathrm{pot}^{-1}\right)>$ Entisols $\left(9.4 \mathrm{mg} \mathrm{P} \mathrm{pot}^{-1}\right)$, Andisols (4.6 mg P pot ${ }^{-1}$ ) and Inceptisols (4.2 $\left.\mathrm{mg} \mathrm{P} \mathrm{pot}^{-1}\right)(p<0.05)$. According to a 2-way ANOVA analysis, land management clearly affected the plant $P$ uptake both of WL and GN, while soil types also clearly affected the plant $\mathrm{P}$ uptake of both (Table 3). Total plant $\mathrm{P}$ uptake was significantly larger in GN than that in WL in whole soil types and managements, except for Incepti-Fer. 
Table 2. Plant biomass, $\mathrm{P}$ concentration, and P uptake after the pot experiment.

\begin{tabular}{|c|c|c|c|c|c|c|c|}
\hline & \multicolumn{2}{|c|}{ Biomass (g pot ${ }^{-1}$ ) } & \multicolumn{2}{|c|}{ P Concentration $\left(\mathrm{mg} \mathrm{P} \mathrm{g}^{-1}\right)$} & \multicolumn{3}{|c|}{ P Uptake (mg P pot $\left.{ }^{-1}\right)$} \\
\hline & Above & Below & Above & Below & Above & Below & Total \\
\hline \multicolumn{8}{|l|}{ White Lupin } \\
\hline Andi-Fer & $\begin{array}{c}7.24 \mathrm{aB} \\
(0.43)\end{array}$ & $\begin{array}{c}2.46 \mathrm{aB} \\
(0.22)\end{array}$ & $\begin{array}{c}3.32 \mathrm{bA} \\
(0.17)\end{array}$ & $\begin{array}{c}2.06 \mathrm{bB} \\
(0.11)\end{array}$ & $\begin{array}{c}23.85 \mathrm{bB} \\
(1.25)\end{array}$ & $\begin{array}{c}5.09 \mathrm{bB} \\
(0.59)\end{array}$ & $\begin{array}{c}28.94 \mathrm{bB} \\
(1.75)\end{array}$ \\
\hline Inceptisols & $\begin{array}{c}0.63 \mathrm{~dB} \\
(0.10)\end{array}$ & $\begin{array}{c}0.43 \mathrm{~dB} \\
(0.16)\end{array}$ & $\begin{array}{c}0.84 \mathrm{dA} \\
(0.03)\end{array}$ & $\begin{array}{c}0.71 \mathrm{cA} \\
(0.03)\end{array}$ & $\begin{array}{c}0.53 \mathrm{cB} \\
(0.10)\end{array}$ & $\begin{array}{c}0.29 \mathrm{cB} \\
(0.10)\end{array}$ & $\begin{array}{c}0.82 \mathrm{~dB} \\
(0.18)\end{array}$ \\
\hline Entisols & $\begin{array}{c}2.06 \mathrm{bcB} \\
(0.08)\end{array}$ & $\begin{array}{c}1.41 \mathrm{cB} \\
(0.18)\end{array}$ & $\begin{array}{c}1.09 \mathrm{dA} \\
(0.05)\end{array}$ & $\begin{array}{c}0.87 \mathrm{cB} \\
(0.06)\end{array}$ & $\begin{array}{c}2.26 \mathrm{cB} \\
(0.11)\end{array}$ & $\begin{array}{c}1.20 \mathrm{cB} \\
(0.12)\end{array}$ & $\begin{array}{c}3.45 \mathrm{cdB} \\
(0.18)\end{array}$ \\
\hline Enti-Fer & $\begin{array}{c}3.20 \mathrm{bB} \\
(0.19)\end{array}$ & $\begin{array}{c}1.53 \mathrm{bcB} \\
(0.05)\end{array}$ & $\begin{array}{c}2.44 \mathrm{cB} \\
(0.20)\end{array}$ & $\begin{array}{c}2.29 \mathrm{bA} \\
(0.12)\end{array}$ & $\begin{array}{c}7.83 \mathrm{cB} \\
(0.85)\end{array}$ & $\begin{array}{c}3.48 \mathrm{bB} \\
(0.17)\end{array}$ & $\begin{array}{c}11.31 \mathrm{cB} \\
(0.93)\end{array}$ \\
\hline \multicolumn{8}{|l|}{ Groundnut } \\
\hline Andi-Fer & $\begin{array}{c}18.34 \mathrm{aA} \\
(0.68)\end{array}$ & $\begin{array}{c}5.46 \mathrm{aA} \\
(0.25)\end{array}$ & $\begin{array}{c}2.28 \mathrm{bB} \\
(0.09)\end{array}$ & $\begin{array}{c}2.50 \mathrm{bA} \\
(0.02)\end{array}$ & $\begin{array}{c}41.75 \mathrm{aA} \\
(1.69)\end{array}$ & $\begin{array}{c}13.61 \mathrm{aA} \\
(0.53)\end{array}$ & $\begin{array}{c}55.36 \mathrm{aA} \\
(1.91)\end{array}$ \\
\hline Inceptisols & $\begin{array}{c}6.25 \mathrm{dA} \\
(0.34)\end{array}$ & $\begin{array}{c}2.50 \mathrm{cdA} \\
(0.15)\end{array}$ & $\begin{array}{c}0.49 \mathrm{cdB} \\
(0.01)\end{array}$ & $\begin{array}{c}0.46 \mathrm{cB} \\
(0.03)\end{array}$ & $\begin{array}{c}3.04 \mathrm{cA} \\
(0.18)\end{array}$ & $\begin{array}{c}1.14 \mathrm{cA} \\
(0.07)\end{array}$ & $\begin{array}{c}4.18 \mathrm{cA} \\
(0.22)\end{array}$ \\
\hline Incepti-Fer & $\begin{array}{c}9.76 \mathrm{cA} \\
(0.56)\end{array}$ & $\begin{array}{c}3.88 \mathrm{bA} \\
(0.35)\end{array}$ & $\begin{array}{c}2.65 \mathrm{abB} \\
(0.23)\end{array}$ & $\begin{array}{c}3.58 \mathrm{aA} \\
(0.31)\end{array}$ & $\begin{array}{c}25.42 \mathrm{bB} \\
(1.12)\end{array}$ & $\begin{array}{c}14.23 \mathrm{aA} \\
(2.22)\end{array}$ & $\begin{array}{c}39.65 \mathrm{bA} \\
(3.07)\end{array}$ \\
\hline Entisols & $\begin{array}{c}6.62 \mathrm{dA} \\
(0.35)\end{array}$ & $\begin{array}{c}2.52 \mathrm{dA} \\
(0.16)\end{array}$ & $\begin{array}{c}0.98 \mathrm{cA} \\
(0.08)\end{array}$ & $\begin{array}{c}1.20 \mathrm{cA} \\
(0.07)\end{array}$ & $\begin{array}{c}6.38 \mathrm{cA} \\
(0.22)\end{array}$ & $\begin{array}{c}3.00 \mathrm{cA} \\
(0.16)\end{array}$ & $\begin{array}{c}9.38 \mathrm{cA} \\
(0.25)\end{array}$ \\
\hline Enti-Fer & $\begin{array}{c}13.00 \mathrm{bA} \\
(0.58)\end{array}$ & $\begin{array}{c}3.60 \mathrm{bcA} \\
(0.26)\end{array}$ & $\begin{array}{c}2.95 \mathrm{aA} \\
(0.10)\end{array}$ & $\begin{array}{c}2.18 \mathrm{bA} \\
(0.12)\end{array}$ & $\begin{array}{c}38.20 \mathrm{aA} \\
(1.65)\end{array}$ & $\begin{array}{c}7.77 \mathrm{bA} \\
(0.43)\end{array}$ & $\begin{array}{c}45.97 \mathrm{bA} \\
(1.53)\end{array}$ \\
\hline
\end{tabular}

Different small letteres indicate significant difference among soils in each plant, according to Tukey test $(p<0.05)$. Different capital letteres indicate significant difference between plants in each soils, according to t-test $(p<0.05)$. Values in parentheses indicate the standard errors of the mean. 
Table 3. Summary of two-way analysis of variance for the effect of soil types (S) and land management (LM) on plant P uptake of white lupin and groundnut.

\begin{tabular}{ccc}
\hline & \multicolumn{2}{c}{ Plant P Uptake } \\
\hline Source & White lupin & Groundnut \\
& F value & F value \\
Soil types (S) & $34.0^{* * *}$ & $13.2^{* * *}$ \\
Land management (LM) & $263.6^{* * *}$ & $965.0^{* * *}$ \\
S $\times$ LM & $44.5^{* * *}$ & $14.0^{* * *}$ \\
\hline &
\end{tabular}

\subsection{Fractionated P of Rhizosphere Soil}

The amount of fractionated P of rhizosphere and $\mathrm{C}_{\mathrm{trl}}$ soil in WL and GN for all soil types and land management are shown in Figures 1-3 and detailed information were also shown in Supplemental Table S1.
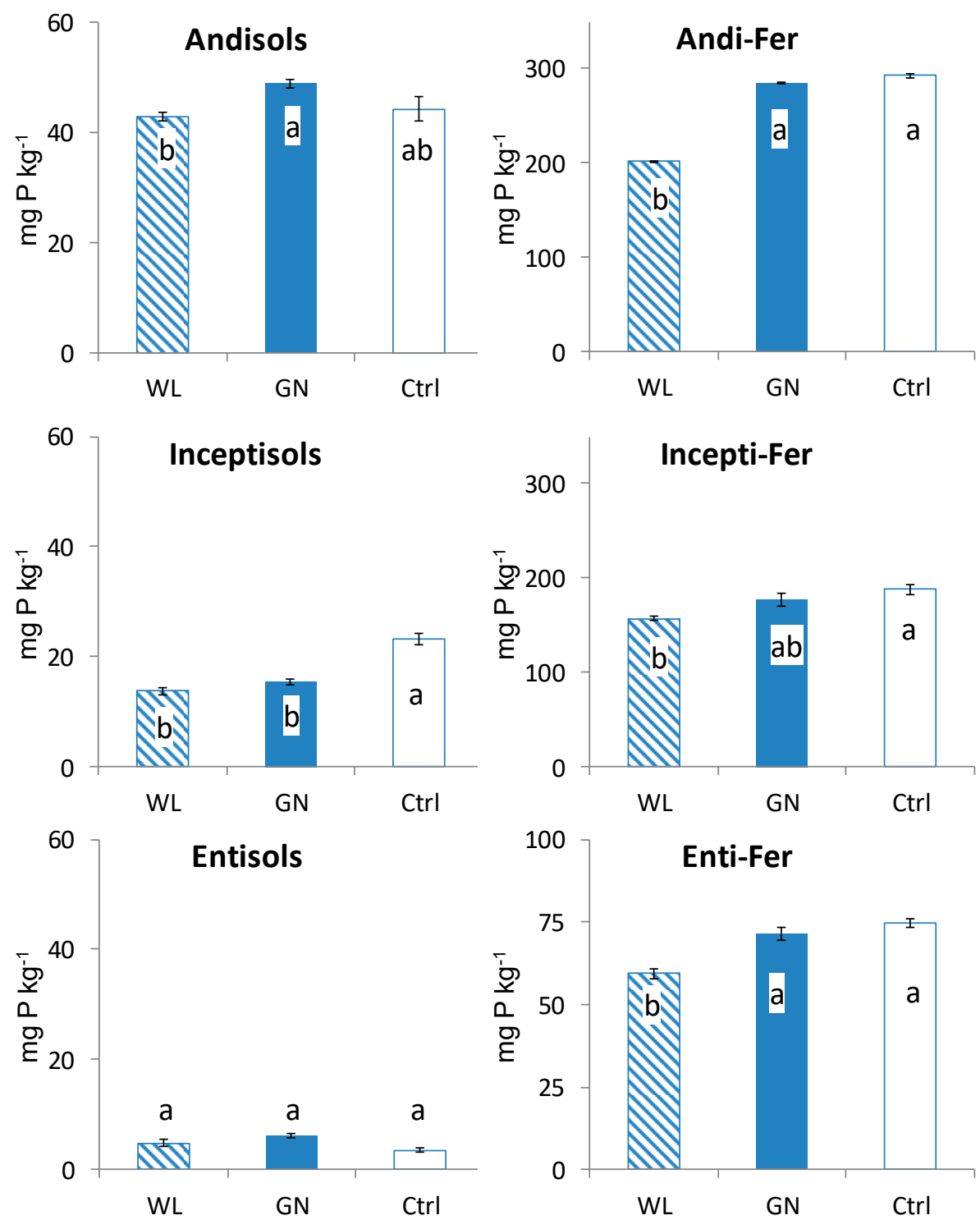

Figure 1. Labile $P$ of white lupin $(\mathrm{WL})$, groundnut $(\mathrm{GN})$ rhizosphere soil, and of control $\left(\mathrm{C}_{\mathrm{trl}}\right)$ soil. Labile $\mathrm{P}=$ Resin- $\mathrm{P}+\mathrm{NaHCO}_{3}-\mathrm{P}_{\mathrm{i}}+\mathrm{NaHCO}_{3}-\mathrm{P}_{\mathrm{o}}$. Different letters indicate significant difference among WL, GN and $\mathrm{C}_{\text {trl }}$ according to Tukey test $(p<0.05)$. 

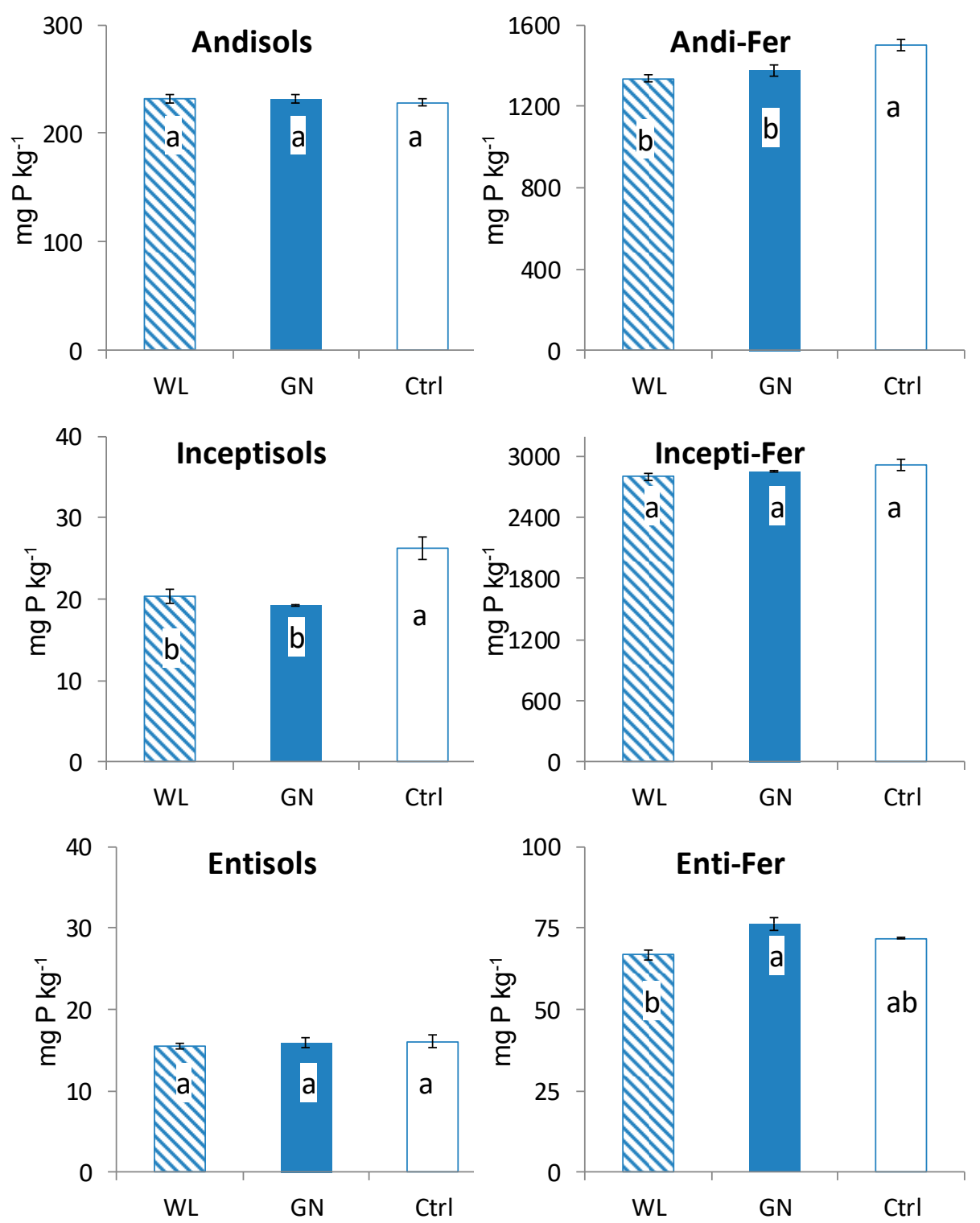

Figure 2. Less labile $\mathrm{Pi}(\mathrm{NaOH}$ extractable $\mathrm{Pi})$ of white lupin (WL), groundnut $(\mathrm{GN})$ rhizosphere soil, and of control (Ctrl) soil. Different letters indicate significant difference among WL, GN and Ctrl according to Tukey test $(p<0.05)$.

WL had significantly decreased the Available $\mathrm{P}$ fractions, i.e., sum of Resin-P, $\mathrm{NaHCO}_{3}-\mathrm{P}_{\mathrm{i}}$, and $\mathrm{P}_{\mathrm{o}}$ contents, in whole soil types and managements, except for Entisols. In case of less labile $\mathrm{P}$ fractions, WL significantly decreased the less labile $\mathrm{P}_{\mathrm{i}}\left(\mathrm{NaOH}-\mathrm{P}_{\mathrm{i}}\right)$ in Andi-Fer, Inceptisols, and Entisols-Fer, and also decreased the less labile $\mathrm{P}_{\mathrm{o}}\left(\mathrm{NaOH}-\mathrm{P}_{\mathrm{o}}\right)$ in Incepti-Fer and Entisols. In contrast, for $\mathrm{GN}$, there was no clear difference for available $\mathrm{P}$ in most soil types and management, except for Inceptisols. GN significantly decreased the less labile $\mathrm{P}_{\mathrm{i}}\left(\mathrm{NaOH}-\mathrm{P}_{\mathrm{i}}\right)$ only in Andi-Fer and Inceptisols.

The effect of WL cultivation on available $\mathrm{P}$ contents of rhizosphere soil was quantitatively larger in P-rich condition soil compared with that in P-poor condition soil, respectively. On the other hand, the effect of GN cultivation on available P contents was a little of both in P-poor and P-rich condition soils, compared with those of WL. In case of the P-rich condition, both WL and GN clearly decreased the less labile $\mathrm{P}_{\mathrm{i}}\left(\mathrm{NaOH}-\mathrm{P}_{\mathrm{i}}\right)$ of rhizosphere soil in Andi-Fer, while only WL decreased the less labile $\mathrm{P}_{\mathrm{o}}$ $\left(\mathrm{NaOH}-\mathrm{P}_{\mathrm{o}}\right)$ and $\mathrm{P}_{\mathrm{i}}(\mathrm{HCl}-\mathrm{P})$ of Incepti-Fer. In Enti-Fer, both WL and GN decreased the available P (esp. Resin-P) but not the less labile P. 

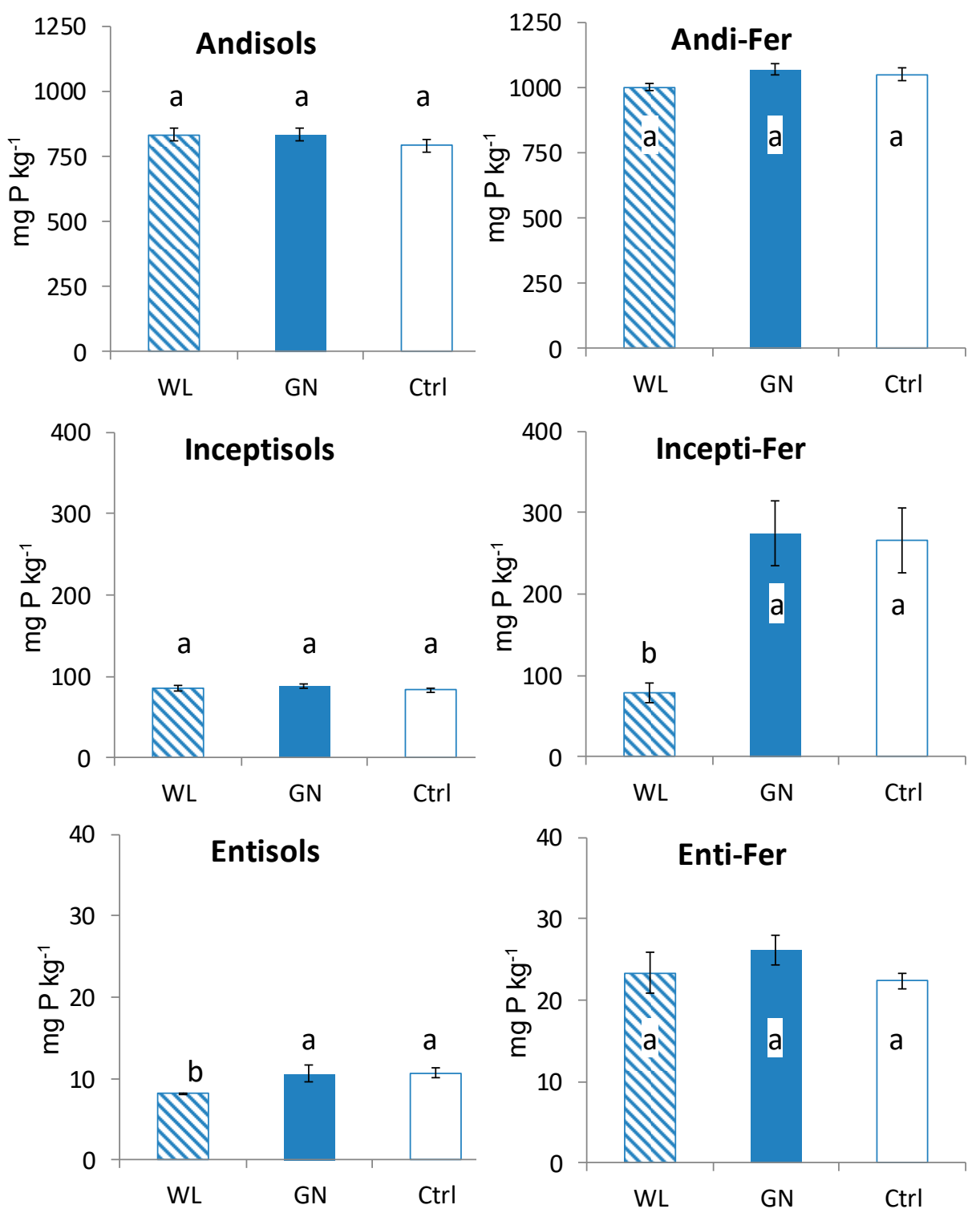

Figure 3. Less labile Po (NaOH extractable $\mathrm{Po})$ of white lupin (WL), groundnut (GN) rhizosphere soil, and of control (Ctrl) soil. Different letters indicate significant difference among WL, GN and Ctrl according to Tukey test $(p<0.05)$.

\subsection{Rhizosphere Soil $p H$}

The soil $\mathrm{pH}$ of rhizosphere of WL and GN and $\mathrm{C}_{\mathrm{trl}}$ for all soil types and management is shown in Figure 4. The rhizosphere soil $\mathrm{pH}$ of WL was clearly lower than that of $\mathrm{C}_{\mathrm{trl}}$ in whole soil types and managements, except for in Andisols and Inceptisols. The rhizosphere soil pH of GN was also clearly lower than that of $C_{\text {trl }}$ in Incepti-Fer, Entisols and Enti-Fer. 

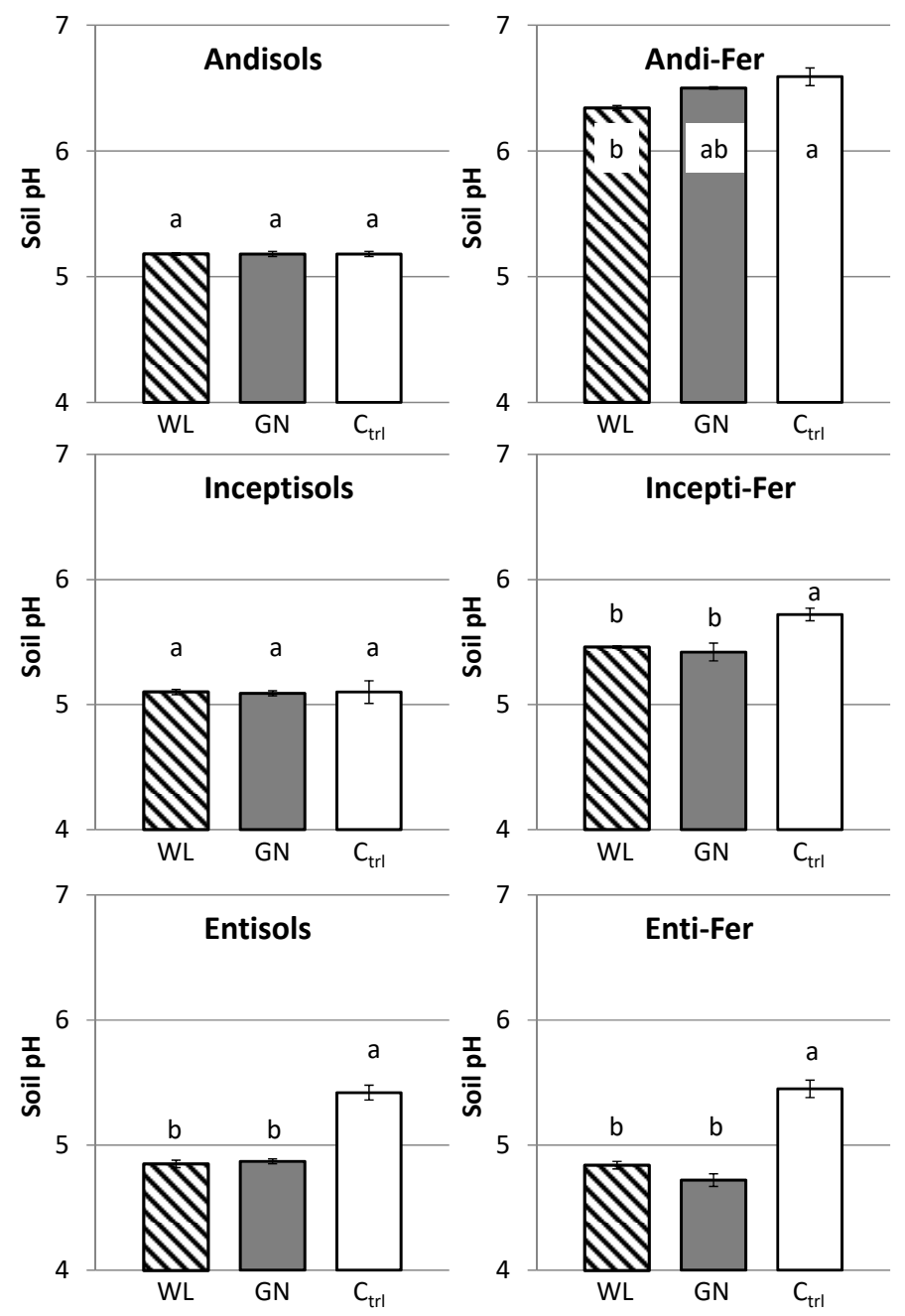

Figure 4. Soil $\mathrm{pH}$ of rhizosphere (WL and $\mathrm{GN})$ and control $\left(\mathrm{C}_{\mathrm{trl}}\right)$ soil after pot experiment; Bar indicates the standard error of mean $(n=5)$; Different letter indicates the significant differences among WL, GN and $\mathrm{C}_{\mathrm{trl}}$ soil in each soil type, according to the Tukey test $(p<0.05)$.

\section{Discussion}

In this study, we observed a clear effect of WL and GN growth on fractionated rhizosphere soil $\mathrm{P}$ of labile and/or less labile $\mathrm{P}$ fraction in different soil types and $\mathrm{P}$ conditions. These results were consistent with those of former studies, which had found the clear WL and GN absorption of labile or less labile $\mathrm{P}$ of soil $[12,29,31,39]$. Because plant $\mathrm{P}$ uptake were clearly larger in P-rich condition than that in P-poor condition, changes in fractionated rhizosphere $\mathrm{P}$ were distinctly observed in P-rich condition of volcanic and red-yellow soils.

\subsection{Comparison of Fractionated Rhizosphere Soil P Dynamics between WL and GN}

In this study, we observed the larger (or similar) GN P uptake than WL P uptake in each soil type and management, which should cause the larger difference of fractionated $\mathrm{P}$ of rhizosphere soil in GN rather than in WL (Table 2). However, in most soil types and managements, the difference of fractionated P of rhizosphere soil was generally clear in WL than that in GN. These results indicate that WL should absorb the specific $P$ forms in each soil type and management, causing clear change of specific $P$ fraction, while GN may absorb the various $P$ forms evenly, resulting in an unclear effect of GN P uptake on labile and less labile P in most soils, except for Andi-Fer and Inceptisols. Many studies have indicated that GN can utilize the less labile $\mathrm{P}$, such as $\mathrm{AlPO}_{4}$ and $\mathrm{FePO}_{4}[29,39]$, and therefore, 
we hypothesized that GN growth should affect the less labile $P$ in various P-limited soils. However, in this study, we observed that GN decreased less labile $\mathrm{P}\left(\mathrm{NaOH}-\mathrm{P}_{\mathrm{i}}\right)$ only in Andi-Fer and Inceptisols, while WL significantly decreased the less labile $\mathrm{P}\left(\mathrm{NaOH}-\mathrm{P}_{\mathrm{i}},-\mathrm{P}_{\mathrm{o}}\right.$, or $\left.\mathrm{HCl}-\mathrm{P}\right)$ in most soils, except for Andisols. This might be because the different mechanisms of less labile P solubilization for WL and GN. WL generally secretes much organic acid and phosphatase from their cluster root and mobilizes the less labile $P_{i}$ and Po $[40,41]$. In contrast, Ae and Shen [42] showed that GN roots can absorb the less labile $\mathrm{P}$ which was $\mathrm{AlPO}_{4}$ or $\mathrm{FePO}_{4}$, by chelating the metallic ion on the root surface rather than by secreting the organic acid, and its chelating solubilization should contribute to GN uptake of less labile $\mathrm{P}$, though the secretion of substantial organic acid from GN roots should also contribute to the solubilization of less labile P [43]. These different P solubilization mechanisms for WL and GN (i.e., a varied spatial distribution of root activity for less labile $\mathrm{P}$ ) are likely to have caused different results in this pot experiment. Most previous studies of the GN P uptake were mostly focused on the effect of applied $\mathrm{P}$ forms, such as $\mathrm{AlPO}_{4}, \mathrm{FePO}_{4} \cdot 4 \mathrm{H}_{2} \mathrm{O}$, and Ca-phytate, on GN P uptake and root activity such as exudates, and therefore, there is little information regarding the real soil $\mathrm{P}$ dynamics under the natural (no-applied) soil P conditions [18,39]. Based on the total plant P uptake, GN should be useful to improve the soil-plant $\mathrm{P}$ dynamics in volcanic and sandy soils, due to its larger $\mathrm{P}$ uptake than $\mathrm{WL}$, though our results also suggest that WL should efficiently solubilize the less labile P than GN, and therefore WL should be useful to utilize the less labile P of soil.

\subsection{Effect of Soil Physico-Chemical Properties on Rhizosphere Soil P Dynamics}

We found that the total WL P uptake was the largest in Incepti-Fer, indicating that WL must solubilize and absorb the substantial less labile P of soil in Incepti-Fer, which has more crystalline Fe than other soils. Many studies have shown that WL secretes much organic acid from its cluster root [44], and Sugihara et al. [22] also observed that WL solubilized NaOH-Pi in Tanzanian fed-rich cropland soil in a similar pot experiment to the current study. However, in this study, we did not observe the decrease of $\mathrm{NaOH}-\mathrm{Pi}$ in Incepti-Fer, while we observed the decrease of $\mathrm{NaOH}_{-} \mathrm{P}_{\mathrm{o}}$ and $\mathrm{HCl}-\mathrm{P}$ in Incepti-Fer. HCl-P is generally considered as Ca associated P (e.g., apatite). Thus, organic acid from the WL root should solubilize the HCl-P instead of the NaOH-P $\mathrm{P}_{\mathrm{i}}$ of Incepti-Fer in this study. On the other hand, in Inceptisols, we had observed the decrease of $\mathrm{NaOH}-\mathrm{P}_{\mathrm{i}}$ both in WL and GN. $\mathrm{NaOH}$ extractable $\mathrm{P}_{\mathrm{i}}$ should be mostly associated with crystalline $\mathrm{Fe}$, because of more $\mathrm{Fe}_{\mathrm{d}}$ and less $\mathrm{Al}_{\mathrm{o}}$ in red-yellow soils. Then, both $\mathrm{WL}$ and GN could solubilize and use the $\mathrm{NaOH}-\mathrm{P}_{\mathrm{i}}$ fraction of much crystalline Fe soil, in case of P deficiency. Furthermore, it was also well known that WL can exude much phosphatase and utilize organic $P$ effectively [45] and we observed the mineralization of NaOH-Po only in Incepti-Fer of WL. Because Po in Andisols and Andi-Fer, which have larger $\mathrm{NaOH}-\mathrm{P}_{\mathrm{o}}$ than the other soil types, were not decreased at all, WL may be able to mineralize the $\mathrm{P}_{\mathrm{o}}$ associated with crystalline Fe in Incepti-Fer [46], but not Po associated with non-crystalline Al. This is possibly because soil organic matter associated with non-crystalline $\mathrm{Al}$ is relatively persistence and therefore stable compared with Fe or other minerals [47,48]. Further study is necessary to evaluate this hypothesis, because Hedley methods can not exactly evaluate the organic P fractions especially in highly weathered soils and Andisols [49,50]. In contrast, GN did not clearly affect the less labile Pi and Po in Incepti-Fer, and the aboveground plant $P$ uptake was also significantly smaller than WL, only in Incepti-Fer. Then, our results indicated that WL can efficiently solubilize and absorb the less labile P in red-yellow soil with fertilization, compared with GN.

We also found that WL and GN significantly decreased NaOH-P $\mathrm{P}_{\mathrm{i}}$ in Andi-Fer, while it was not in Andisols, though P absorption capacities were similarly high both in Andi-Fer and Andisols. Considering the substantially larger total P uptake of WL and GN in Andi-Fer than those in Andisols, both WL and GN can solubilize and absorb the NaOH-P fraction only in Andi-Fer, caused by larger (and possibly stronger) plant $\mathrm{P}$ uptake based on developed root systems. Because of the larger amount of $\mathrm{Al}_{\mathrm{o}}$ and volcanic soil material of Andi-Fer and Andisols, the accumulated less labile $\mathrm{P}_{\mathrm{i}}\left(\mathrm{NaOH}-\mathrm{P}_{\mathrm{i}}\right)$ of these soils should be mostly associated with non-crystalline Al. The possible reasons of the above 
different $\mathrm{P}$ dynamics for Andisols and Andi-Fer were as follows: (1) The different soil $\mathrm{pH}$ for Andisols (5.3) and Andi-Fer (6.7) (Table 1), and (2) the different history of land use for Andisols (uncultivated) and Andi-Fer (cultivated with continuous chemical fertilizer and compost addition). For the first reason, $\mathrm{P}$ availability of soil is strongly limited under acidic conditions. Lambers et al. [11] showed that soil $\mathrm{pH}$ affects the $\mathrm{P}$ forms and their stability, and the low soil $\mathrm{pH}$ (4.7-5.2) in volcanic soils must cause low $\mathrm{P}$ availability for most plants, though $\mathrm{P}$ availability of soil should increase with the increase of soil $\mathrm{pH}$. Ae et al. [17] also observed that $\mathrm{pH}$ reclamation of acidic soil increased the GN P uptake in volcanic soil of Japan. For the second reason, because of the long term cultivation with organic and inorganic fertilizer for more than 25 years in Andi-Fer, labile and less labile Pi is substantially larger in Andi-Fer than in Andisols. On the basis of these results, both WL and GN can solubilize and utilize the less labile $\mathrm{Pi}$ associated with non-crystalline $\mathrm{Al}$ of volcanic soil, which has high $\mathrm{P}$ absorption capacity, under adequate soil $\mathrm{pH}$ and continuous fertilizer managed cropland, though further study is necessary to reveal the effect of soil $\mathrm{pH}$ and land management on P solubilization by P-efficient legumes separately, by XANES or 31P-NMR analysis [14,51]. In addition, in case of GN, total P uptake was significantly larger in Andi-Fer than in Incepti-Fer, though the $\mathrm{P}$ adsorption capacity was significantly larger in Andi-Fer than in Incepti-Fer and Avail-P was similar. It may indicate that GN can absorb the less labile $\mathrm{P}_{\mathrm{i}}$ associated with non-crystalline $\mathrm{Al}$ under adequate soil $\mathrm{pH}$ and continuous fertilizer management of volcanic soils rather than $\mathrm{Fe}$ associated less labile $\mathrm{P}$, such as red-yellow soils.

Supplementary Materials: The following are available online at http:/ / www.mdpi.com/2073-4395/9/2/68/s1, Table S1: Amount of fractionated and total soil P of rhizosphere soil and Ctrl after the pot experiment.

Author Contributions: Conceptualization: S.S., J.W. and H.T.; data curation: K.I. and S.S.; investigation: K.I., S.S. and H.T.; methodology, S.S. and J.W.; project administration: S.S.; writing-original draft: K.I.; writing-review and editing, S.S., J.W. and H.T.

Funding: This research and APC was funded by the Japanese Society for the Promotion of Science KAKENHI, Grant Numbers \#17H06171 and 18KK0185.

Acknowledgments: We thank T. Motobayashi and the staffs of the Faculty of Agricultural Field Science Center, Tokyo University of Agriculture and Technology, for their kind technical support in the field survey and soil sampling in Japan.

Conflicts of Interest: The authors declare no conflict of interest.

\section{References}

1. Holford, I.C.R. Soil phosphorus; its measurement, and its uptake by plants. Aust. J. Soil Res. 1997, 35, 227-239. [CrossRef]

2. Takahashi, T.; Dahlgren, R.A. Nature, properties and function of aluminum-humus complexes in volcanic soils. Geoderma 2016, 263, 110-121. [CrossRef]

3. Nuruzzaman, M.; Lambers, H.; Bolland, M.D.A.; Veneklaas, E.J. Phosphorus benefits of different legume crops to subsequent wheat grown in different soils of Western Australia. Plant Soil 2005, 271, $175-187$. [CrossRef]

4. Raghothama, K.G.; Karthikeyan, A.S. Phosphate acquisition. Plant Soil 2005, 274, 37-49. [CrossRef]

5. Cordell, D.; Drangert, J.O.; White, S. The story of phosphorus: Global food security and food thought. Glob. Environ. Chang. 2009, 19, 292-305. [CrossRef]

6. Vance, C.P.; Uhde-Stone, C.; Allan, D.L. Phosphorus acquisition and use: Critical adaptations by plants for securing a nonrenewable resource. New Phytol. 2003, 157, 423-447. [CrossRef]

7. Van Vuuren, D.P.; Bouwman, A.F.; Beusen, A.H.W. Phosphorus demand for the 1970-2100 period: A scenario analysis of resource depletion. Glob. Environ. Chang. 2010, 20, 428-439. [CrossRef]

8. Rose, T.J.; Hardiputra, B.; Rengel, Z. Wheat, canola and grain legume access to soil phosphorus fractions differs in soils with contrasting phosphorus dynamics. Plant Soil 2010, 326, 159-170. [CrossRef]

9. Hassan, H.M.; Hasbullah, H.; Marschner, P. Growth and rhizosphere P pools of legume-wheat rotations at low P supply. Biol. Fertil. Soils 2013, 49, 41-49. [CrossRef] 
10. Nuruzzaman, M.; Lambers, H.; Bolland, M.D.A.; Veneklaas, E.J. Phosphorus uptake by grain legumes and subsequently grown wheat at different levels of residual phosphorus fertilizer. Aust. J. Agric. Res. 2005, 56, 1041-1047. [CrossRef]

11. Lambers, H.; Bishop, J.G.; Hopper, S.D.; Laliberte, E.; Zúñiga-Feest, A. Phosphorus-mobilization ecosystem engineering: The roles of cluster roots and carboxylate exudation in young P-limited ecosystems. Ann. Bot. 2012, 110, 329-348. [CrossRef] [PubMed]

12. Wang, Y.; Marschner, P.; Zhang, F. Phosphorus pools and other soil properties in the rhizosphere of wheat and legumes growing in three soils in monoculture or as a mixture of wheat and legme. Plant Soil 2012, 360, 271-298. [CrossRef]

13. Maltais-Landry, G. Legumes have a greater effect on rhizosphere properties ( $\mathrm{pH}$, organic acids and enzyme activity) but a smaller impact on soil P compared to other cover crops. Plant Soil 2015, 394, 139-154. [CrossRef]

14. Turner, B.L.; McKelvie, I.D.; Haygarth, P.M. Characterisation of water-extractable soil organic phosphorus by phosphatase hydrolysis. Soil Biol. Biochem. 2002, 34, 27-35. [CrossRef]

15. Gerke, J.; Romer, W.; Jungk, A. The excretion of citric and malic acid by proteoid roots of Lupinus albus L.; effects on soil solution concentrations of phosphate, iron, and aluminum in the proteoid rhizosphere in samples of an oxisol and a luvisol. J. Plant Nutr. Soil Sci. 1994, 157, 289-294.

16. Shane, M.W.; Lambers, H.; Cawthray, G.R.; Kuhn, A.J.; Schurr, U. Impact of phosphorus mineral source (Al-P or Fe-P) and $\mathrm{pH}$ on cluster-root formation and carboxylate exudation in Lupinus albus L. Plant Soil 2008, 304, 169-178. [CrossRef]

17. Ae, N.; Otani, T.; Makino, T.; Tazawa, J. Role of cell wall of groundnut roots in solubilizing sparingly soluble phosphorus in soil. Plant Soil 1996, 186, 197-204. [CrossRef]

18. Shibata, R.; Yano, K. Phosphorus acquisition from non-labile sources in peanut and pigeonpea with mycorrhizal interaction. Appl. Soil Ecol. 2003, 24, 133-141. [CrossRef]

19. Ae, N.; Arihara, J.; Okada, K.; Yoshihara, T.; Johansen, C. Phosphorus uptake by pigeon pea and its role in cropping system of the Indian subcontinent. Science 1990, 248, 447-480. [CrossRef]

20. Gerke, J. The acquisition of phosphate by higher plants: Effect of carboxylate release by the roots. A critical review. J. Plant Nutr. Soil Sci. 2015, 178, 351-364. [CrossRef]

21. Hinsinger, $\mathrm{H}$. Bioavailability of soil inorganic $\mathrm{P}$ in the rhizosphere as affected by root-induced chemical changes: A review. Plant Soil 2001, 237, 173-195. [CrossRef]

22. Sugihara, S.; Tomita, Y.; Nishigaki, T.; Kilasara, M.; Wasaki, J.; Funakawa, S. Effects of different phosphorus-efficient lugumes and soil texture on fractionated rhizosphere soil phosphorus of strongly weathered soils. Biol. Fertil. Soils 2016, 52, 367-376. [CrossRef]

23. Dissanayaka, D.M.S.B.; Maruyama, H.; Masuda, G.; Wasaki, J. Interspecific facilitation of P acquisition in intercropping of maize with white lupin in two contrasting soils as influenced by different rates and forms of P supply. Plant Soil 2015, 390, 223-236. [CrossRef]

24. Gunjigake, N.; Wada, K. Effects of phosphorus concentration and $\mathrm{pH}$ on phosphate retention by active aluminiumu and iron of Ando Soils. Soil Sci. 1981, 132, 347-352. [CrossRef]

25. Otani, T.; Ae, N. The status of inorganic and organic phosphorus in some soils in relation to plant availability. Soil Sci. Plant Nutr. 1997, 43, 419-429. [CrossRef]

26. Freese, D.; van der Zee, S.E.A.T.M.; van Riemsdijk, W.H. Comparison of different models for phosphate sorption as a function of the iron and aluminium oxides of soils. J. Soil Sci. 1992, 43, 729-738. [CrossRef]

27. Takahashi, S.; Anwar, M.R. Wheat grain yield, phosphorus uptake and soil phosphorus fraction after 23 years of annual fertilizer application to an Andosol. Field Crop. Res. 2007, 101, 160-171. [CrossRef]

28. Kinjo, K.; Tokashiki, Y.; Kitou, M. Chemical and Mineralogical properties and humic substances of soils cultivated with sugacane in Kita and Minami Daito Island, Japan. Res. Trop. Agric. 2009, 2, 80-84. (In Japanese)

29. Otani, T.; Ae, N.; Tanaka, H. Phosphorus (P) uptake mechanisms of crops grown in soils gwoth low P status. Soil Sci. Plant Nutr. 1996, 42, 553-560. [CrossRef]

30. Nwoke, O.C.; Vanlauwe, B.; Diels, J.; Sanginga, N.; Osounbi, O.; Merckx, R. Assessment of labile phosphorus fractions and adsorption characteristics in relation to soil properties of West African savanna soils. Agric. Ecosyst. Environ. 2003, 100, 285-294. [CrossRef] 
31. Nuruzzaman, M.; Lambers, H.; Bolland, M.D.A.; Veneklaas, E.J. Distribution of carboxylates and acid phosphatase and depletion of different phosphorus fractions in the rhizosphere of a cereal and three grain legumes. Plant Soil 2006, 281, 109-120. [CrossRef]

32. Hedley, M.J.; Stewart, J.W.B.; Chauhan, B.S. Changes in inorganic and organic soil phosphorus fractions induced by cultivation practices and by laboratory incubations. Soil Sci. Soc. Am. J. 1982, 46, 970-976. [CrossRef]

33. Wright, A.L. Soil phosphorus stocks and distribution in chemical fractions for long-term sugarcane, pasture, turfgrass, and forest systems in Florida. Nutr. Cycl. Agroecosyst. 2009, 83, 223-231. [CrossRef]

34. Soil Survey Staff. Key to Soil Taxonomy, 10th ed.; USDA-Natural Resources Conservation Service: Washington, DC, USA, 2006.

35. Sekiya, K. Phosphoric acid. In Analysis Methods for Measuring Soil Fertility; Ishizawa, S., Ed.; Yokendo Co. Ltd.: Tokyo, Japan, 1970; pp. 251-253.

36. Murphy, J.; Reley, J.P. A modified single solution method for the determination of phosphate in natural waters. Anal. Chim. Acta 1962, 27, 31-36. [CrossRef]

37. Kitson, R.; Mellon, M.G. Colorimetric determination of phosphorus as molybdivanadophosporic acid. Ind. Eng. Chem. Anal. Ed. 1944, 16, 379-383. [CrossRef]

38. Negassa, W.; Leinweber, P. How does the Hedley sequential phosphorus fractionation reflect impacts of land use and management on soil phosphorus: A review. J. Soil Sci. Plant Nutr. 2009, 172, 305-325. [CrossRef]

39. Wissuwa, M.; Ae, N. Genotypic variation for phosphorus uptake from hardly soluble ironphosphate in groundnut (Arachis hypogaea L.). Plant Soil 1999, 206, 163-171. [CrossRef]

40. Li, H.G.; Shen, J.B.; Zhang, F.S.; Marschner, P.; Cawthray, G.; Rengel, Z. Phosphorus uptake and rhizosphere properties of intercropped and monocropped maize, faba bean, and white lupin in acidic soil. Biol. Fertil. Soils 2010, 46, 79-91. [CrossRef]

41. Wasaki, J.; Yamamura, T.; Shinano, T.; Osaki, M. Secreted acid phosphatase is expressed in cluster roots of lupin in response to phosphorus deficiency. Plant Soil 2003, 248, 129-136. [CrossRef]

42. Ae, N.; Shen, R.F. Root cell-wall properties are proposed to contribute to phosphorus (P) mobilization by groundnut and pigeonpea. Plant Soil 2002, 245, 95-103. [CrossRef]

43. Ohwaki, Y.; Hirata, H. Differences in carboxylic acid exudation among p-starved leguminous crops in relation to carboxylic acid contents in plant tissues and phospholipid level in roots. Soil Sci. Plant Nutr. 1992, 38, 235-243. [CrossRef]

44. Wang, X.; Pearse, S.J.; Lambers, H. Cluster-root formation and carboxylate release in three Lupinus species as dependent on phosphorus supply, internal phosphorus concentration and relative growth rate. Ann. Bot. 2013, 112, 1449-1459. [CrossRef] [PubMed]

45. Le Bayon, R.C.; Weisskopf, L.; Martinoia, E.; Jansa, J.; Frossard, E.; Keller, F.; Follmi, K.B.; Gobat, J.M. Soil Phosphorus Uptake by Continuously Cropped Lupinus albus: A New Microcosm Design. Plant Soil 2006, 283, 309-321. [CrossRef]

46. George, T.S.; Gregory, P.J.; Robinson, J.S.; Buresh, R.J. Changes in phosphorus concentrations and pH in the rhizosphere of some agroforestry and crop species. Plant Soil 2002, 246, 65-73. [CrossRef]

47. Wagai, R.; Kajiura, M.; Asano, M.; Hiradate, S. Nature of soil organo-mineral assemblage examined by sequential density fractionation with and without sonication: Is allophanic soil different? Geoderma 2015, 241, 295-305. [CrossRef]

48. Rasmussen, C.; Heckman, K.; Wieder, W.R.; Keiuluweit, M.; Lawrence, C.R. Beyond clay: Towards an improved set of variables for predicting soil organic matter content. Biogeochemistry 2018, 137, 297-306. [CrossRef]

49. Turner, B.L.; Cade-Menun, B.J.; Condron, L.M.; Newman, S. Extraction of soil organic phosphorus. Talanta 2005, 66, 294-306. [CrossRef]

50. Velásquez, G.; Ngo, P.T.; Rumpel, C.; Calabi-Floody, M.; Redel, Y.; Turner, B.L.; Condron, L.M.; Mora, M.L. Chemical nature of residual phosphorus in Andisols. Geoderma 2016, 271, 27-31. [CrossRef]

51. Kar, G.; Hilger, D.; Schienau, J.J.; Peak, D. Effects of plant growth and time on phosphorus speciation in a manure-amended Prairie soil under controlled conditions. Rhizosphere 2017, 4, 1-8. [CrossRef]

(C) 2019 by the authors. Licensee MDPI, Basel, Switzerland. This article is an open access article distributed under the terms and conditions of the Creative Commons Attribution (CC BY) license (http:/ / creativecommons.org/licenses/by/4.0/). 